\title{
PENGEMBANGAN SUMBERDAYA MANUSIA DALAM PELAYANAN PUBLIK (Studi Kasus PT. Tirta Remu Kota Sorong)
}

\author{
Ana Lestari ${ }^{1}$, Siti Nurul Nikmatul Ula ${ }^{2}$, Miryam Diana Kalagison ${ }^{3}$ \\ Program Studi Ilmu Administrasi Negara, FISIP, Universitas Muhammadiyah Sorong. \\ Indonesia \\ Program Studi Sosiologi, FISIP, Universitas Muhammadiyah Sorong. Indonesia \\ Program Studi Ilmu Administrasi Negara, FISIP, Universitas Muhammadiyah Sorong. \\ Indonesia \\ *Korespondensi: miakalagison@gmail.com
}

\begin{abstract}
PT. Tirta Remu, Sorong City, which is a Regional Company, including administrative and management activities that must be managed by employees according to their duties and functions, so that they can achieve common goals, in this case the performance of employees of PT. Tirta Remu is still not optimal because of the organizational culture still not well directed, so an organizational culture is needed. This researcher is a descriptive study with a qualitative approach. The data study techniques used in this study are interviews, observation and documentation. Based on the results of the research shows that the implementation related to the development of human resources at PT.Tirta Remu in the city of Sorong in 2015 has not been effective, due to supporting and inhibiting factors (awareness factors, regulatory factors, organizational factors, income factors, abilities and skills as well as factors facilities and infrastructure), the lack of education and training that is still lacking and urgently needed by employees, and a lack of cooperation between leaders and subordinates.
\end{abstract}

Keywords : Development, Human Resourcer, Public Service

\begin{abstract}
ABSTRAK
PT. Tirta Remu Kota Sorong yang merupakan Perusahaan Daerah yang di dalamnya meliputi kegiatan administrasi dan manajemen yang harus dikelola oleh para pegawai sesuai dengan tugas dan fungsinya untuk dapat mencapai tujuan bersama, dalam hal ini kinerja pegawai dari PT. Tirta Remu masih belum optimal dikarenakan budaya organisasi yang masih belum terarah dengan baik, sehingga diperlukan adanya budaya organisasi. Peneliti ini merupakan penelitian deskriptif dengan pendekatan kualitatif. Teknik pengumpulan data yang dipakai dalam penelitian ini dengan cara wawancara, observasi dan dokumentasi. Berdasarkan penelitian bahwa pelakasanaan terkait pengembangan sumberdaya manusia pada PT. Tirta Remu di kota sorong tahun 2015 belum efektif, karena adanya faktor pendukung dan faktor penghambat (faktor kesadaran, faktor aturan, faktor organisasi, faktor pendapatan, kemampuan dan ketrampilan serta faktor sarana dan prasarana), adanyapendidikan dan pelatihan yang masih kurang dan sangat di perlukan oleh karyawan, serta kurangnya kerja sama bawahan dengan pimpinan.
\end{abstract}

Kata Kunci: Pengembangan, Sumberdaya Manusia, Pelayanan Publik

PENDAHULUAN

Kebijakan pemerintah mengenai Otonomi Daerah yang merupakan salah 
satu upaya dalam rangka melimpahkan kewenangan kepada Pemerintah Daerah yang bertujuan meningkatkan pelayanan publik guna kesejahteraan masyarakat (Undang-UndangRepublik Indonesia Nomor 22 Tahun 1999).

Otonomi Daerah menuntut untuk berusaha memajukan daerah dengan adanya partisipasi masyarakat, menganalisa aspirasi rakyat dalam menajalankan kebijakan-kebijakan.

PT. Tirta Remu Kota Sorong yang merupakan Perusahaan Daerah yang di dalamnya meliputi kegiatan administrasi dan manajemen, yang mana harus dikelola oleh anggota organisasi atau para pegawai yang baik dan bertanggung jawab sesuai dengan tugas dan fungsinya, sehingga dapat mencapai tujuan bersama.

Untuk mewujudkan hal tersebut diperlukan adanya budaya organisasi dalam upaya memberikan pengarahan dan penyebaran kepercayaan, juga nilai-nilai yang berkembang dalam suatu organisasi dalam mengarahkan anggota organisasinya.

Budaya organisasimerupkan tata nilai yang di sepakati dan di patuhi oleh seluruh anggota organisasi yang sifatnya dinamis dan mampu meningkatatkan produktivitas kerjaorganisasi (Sudaryono 2017:7).

Kinerja merupakan petunjuk kerja yang dapat di capai oleh seseorang dalam melakukan tugas-tugas pekerjaanya sesuai dengan kewenagan dan tanggung jawabnya dalam upaya mencapai tujuan organisasi dengan indikator menyelesaikan tugas dengan baik dan benar, mentaati prosedur dan aturan kerja, memiliki inisiatif dalam bekerja, menjaga kualitas kerja, berprilaku baik dan tanggap terhadap peningkatan tuntutan kerja, menetapkan tujuan yang telah di tetapkan sesuai agenda (Sudaryono 2017).

Jadi manusia sebagai penggerak dalam suatu organisasi harus dikembangkan melalui pendidikan dan pelatihan karena akan berdampak positif pada terciptanya etos kerja yang produktif, memiliki keterampilan, kreatifitas, disiplin, profesional serta memiliki kemampuan untuk mengembangkan, menguasai ilmu pengetahuan maupun kemampuan manajemen, serta dapat memperhitungkan segala sumber daya yang ada, sehingga dapat memberikan kesejahteraan bagi karyawan, yang mana kesejahteraan yang diberikan kepada karyawan hendaknya harus bermanfaat dan dapat mendorong untuk tercapainya tujuan perusahaan. 
Berdasarkan obeservasi yang peneliti lakukan ditemukan sebagai berikut: 1) Sebagian pegawai kurang berinisiatif dalam mengerjakan tugas yang diperintahkan pimpinan. 2) Kemampuan yang dimiliki pegawai masih kurang maksimal dalam mengerjakan pekerjaannya. 3) Kurangnya komunikasi secara langsung dengan rekan kerja.

Dari indikasi diatas menunjukkan kinerja pegawai masih belum optimal, yang mana disebabkan oleh budaya organisasi yang masih belum baik. Hal ini sesuai dengan beberapa indikasi yang ditemukan sebagai berikut. 1) Kurang adanya sistem imbalan seperti reward materiil dan promosi dari pimpinan sebagai penghargaan kepada pegawai yang berprestasi. 2) Kurang adanya keberanian dari tiap pegawai dalam mengambil resiko terhadap tindakan-tindakan yang dilakukan. 3) Kurangnya dorongan bagi pegawai untuk bekerja secara terkoordinasi dalam bekerja.

Berdasarkan uraian di atas, penulis tertarik untuk melakukan penelitian dengan judul Pengembangan Sumber Daya Manusia dalam Pelayanan Publik (Studi Kasus PT. Tirta Remu Kota Sorong)

\section{METODE}

Penelitian ini berusaha memaparkan realitas yang menggambarkan suatu keadaan beserta segala aspeknya dalam rangka pemberian informasi sejelasjelasnya tentang Pengembangan Sumber Daya Manusia dalam Pelayanan Publik di PT. Tirta Remu Kota Sorong. Metode yang digunakan adalah pendekatan kualitatif dan berbentuk diskriptif sebagai prosedur atau tatacara dalam penelitian yang menghasilkan data deskriptif kualitatif berupa kata-kata tertulis maupun lisan dari orang-orang dan perilaku yang dapat diamati (Burhan Bungin 2007).

Jenis penelitian yang digunakan dalam penelitian ini adalah studi kasus dengan tujuannya untuk mendapatkan masukan-masukan dari para karyawan yang bekerja di PT. Tirta Remu Kota Sorong itu sendiri mengenai pengembangan sumberdaya manusia mulai dari faktor pendukung dan penghambat dari pelayanan pada PT. Tirta Remu Kota Sorong.

Prosedur perolehan data penelitian kualitatif diperoleh dari observasi dengan mengamati secara langsung objek yang diteliti (Sugiyono 2011), sehingga penulis mendapatkan apa yang ingin diketahui mengenai perilaku karyawan atau staf pada saat melakukan pelayanandan melakukan 
wawancara secara langsung dengan para karyawan atau staf dari kantor PT. Tirta Remu Kota Sorong, serta melakukan dokumentasi terhadap proses pengambilan data. Setelah data-data terkumpul, kemudian di analisis dan disajikan sesuai variabel-variabel yang dijadikan indikatorindikator dalam penelitian ini, untuk selanjutnya dapat memberikan gambaran dan masukan yang jelas bagi peneliti tentang Pengembangan Sumber Daya Manusia Dalam Pelayanan Publik Pada PT. Tirta Remu Kota Sorong.

\section{HASIL DAN PEMBAHASAN}

\section{Pengembangan SDM dalam Pelayanan Publik Pada PT.Tirta Remu Kota Sorong}

$$
\text { Pengembangan sumberdaya }
$$
manusia mempunyai dampak signifikan terhadap pelayanan pada PT. Tirta Remu Kota Sorong, untuk merealisasikan maksud tersebut perlua adanya suatu perencanaan yang dilakukan oleh PT. Tirta Remu untuk membenahi, para aparaturnya yang belum memiliki kemampuan teknis dan konsep. Sehinggakedepan diharapkan produktivitas dari para pegawai dapat mewujudkan kesejahteraan bagi seluruh masyarakat yang ada (Sulistiyani 2019).
Bagian atau unit yang biasanya menguasai sumber daya manusia adalah depertemen sumber daya manusia atau human resource department yang meliputi segi perencanaan, pengorganisasian, pelaksanan dan pengendalian (Dessler 2011).

Sumber daya manusia sangat penting peranannya dalam pencapaian tujuan bersama, maka sumber daya manusia dalam suatu organisasi atau suatu lembaga harus dapat menerapkan peranan manusia atau staf yang ada pada lembaga tersebut yaitu PT. Tirta Remu di kota sorong papua barat, dikarenakan manusia merupakan motor penggerak bagi maju mundurnya suatu organisasi, maka penting untuk tujuan organisasi secara efektif dan efisien.

Begitu pula dengan PT. Tirta Remu Kota Sorong harus mampu menciptakan manusia yang berkualitas, kreatif sehingga mampu melaksanakan tugas dan tanggung jawab dengan sebaik-baiknya demi tercapainya tujuan dan dapat memberikan pelayanan kepada masyarakat. Agar fungsi dan tujuan itu dapat tercapai sebagaimana yang di harapkan, oleh sebab itu perlu didukung dengan sumber daya manusia dalam arti kuantitas maupun kualitas. 
Kenyataan yang menunjukan pelaksanan sumber daya manusia pada PT. Tirta Remu Kota Sorong tidak berjalan dengan maksimal. Semua itu belum ada penunjukan prestasi yang baik sebagimana di harapkan maka penulis berkesimpulan dari gejala-gejala pelaksanaan yang ada maka yang dihadapi adalah sebagai berikut: 1) Perlu adanya pendidikan dan pelatihan bagi para pegawai. 2) Penerapan system manajemen yang baik dan tetap berpatokan pada fungsi dan manajemen tidak diterapkan oleh pemimpin drengan tepat. 3) Belum adanya pengembangan dalam peningkatan kinerja pegawai.

Mengenai hasil penelitian yang telah diperoleh peneliti selama ini melalui observasi dan wawancara dengan beberapa karyawan atau staf dari PT. Tirta Remu terkait dengan pelayanan yang diberikan kepada konsumen, oleh karena itu salah satu karyawan di PT. Tirta Remu mengatakan bahwa :

PT. Tirta Remu merupakan suatu berkah bagi masyarakat di kota sorong karena dengan adanya PT. Tirta Remu ini masyarakat kota sorong dapat mengkomsumsikan air bersih dan dapat memperoleh kemudahan dalam beraktifitas sehari-hari serta memberikan banyak manfaat yang lain bagi masyarakat kota sorong (November 2019).
Dengan adanya pegawai sebagai sumber daya manusia adalah faktor sentral dalam suatu organisasi. Apapun bentuk serta tujuanya, organisasi dibuat berdasarkan berbagai visi untuk kepentingan manusia dan dalam pelaksanaan misinya dikelola dan di urus oleh manusia.

Banyak organisasi publik dan swasta yang berupaya untuk mempertahankan keberadaan atau eksitensi perusahan ataupun organisasinya, danbanyak pula upaya dari organisasi publik dan swasta yang menekankan kepada karyawan ataupun pegawainya untuk dibina lebih mendalam, yang dimaksudkan akan memberikan pengaruh pada kinerja dan memberikan output bagi organisasi. Upaya organisasi dalam pembinaan dan peningkatan pegawainya dalam menajemen sumber daya manusia sangat berfariasi antara organisasi publik maupun organisasi privat. Keberagaman dari upaya tersebut tergambar pada nilainilai yang coba ditanamkan organisasi pada pegawainya (Melayu SP Hasibuan, 2007). Sehingga harapan dari peningkatkan SDM dapat memenuhi standar yang diinginkan PT. Tirta Remu. Dan adapun visi misi PT. Tirta Remu yang dikemukakan oleh direktur yaitu ibu 
Sophia Manuhutu. AMD di kediaman beliau sebagai berikut:

Visi PT. Tirta Remu adalah Menjadi Perusahaan Sehat Berwawasan Lingkungan terhadap sumber daya manusia SDM yang ada di kota sorong. (November 2019).

Perusahaan PT. Tirta Remu Kota Sorong adalah salah satu perusahaan yang mempunyai kompetensi di bidang urusan air minum khususnya di Kota Sorong. PT. Tirta Remu Kota Sorong mempunyai tugas dan fungsi untuk menyelenggarakan penyediaan air minum dan pengelolaan limbah untuk kesejahteraan masyarakat. Tugas dan fungsi tersebut adalah dalam rangka membantu kelancaranpelaksanaan kekuasaa didaerah,yaitu Bupati/Walikota.

PT. Tirta Remu Kota Sorong memiliki pelanggan yang cukup banyak. Ini sebagai acuan untuk lebih meningkatkan kualitas pelayanan lebih baik, sehingga dapat mencapai tujuan bersama yang diinginkan, hal ini sebagaimana yang di kemukakan oleh salah satu karyawan PT. Tirta Remu Kota Sorong yakni bapak Tomi Napitapulu mengatakan bahwa tujuan perusahaan PT. Tirta Remu Kota Sorong yaitu :

Untuk mengetahui pengembanagan Sumber Daya Manusia (SDM) terhadap pelayanan publik kepada masyarakat kota sorong sehingga dapat membantu kelancaran pelaksanaan penyediaan air bersih (November 2019).

PT. Tirta Remu Kota Sorong merupakan badan operasional yang dibentuk oleh pemerintah daerah Propinsi sebagai penyedia air bersih dan beroperasi dibawah petunjuk pemerintah pusat. PT. Tirta Remu Kota Sorong beroperasi sebagai perusahaan di tingkat wilayah dan bertanggung jawab kepada Bupati atau Walikota. Apabila dilihat dari sisi pelayanan, diberlakukannya UndangUndang No. 22 tahun 2021 Tentang Pemerintahan Daerah, yang telah memberikan perluasan dan kewenangan pada tingkat pemerintah daerah, dipandang sebagai salah satu upaya untuk memotong hambatan birokratis yang acapkali mengakibatkan pemberian pelayanan memakan waktu yang lama dan berbiaya tinggi ( Undang-undang No 22 2001).

Dengan adanya desentralisasi, pemerintah pusat, membuat berbagai kewenangan yang harus dilaksanakan oleh pemerintah daerah, konsekuensi pelayanan yang harus disediakan.Pemerintah daerah memberikan pelayanan yang lebih berkualitas, dalam arti lebih berorientasi kepada aspirasi masyarakat, lebih efisien, efektif dan bertanggung jawab (accountable) Waluyo, 2007. Kualitas 
pelayanan dapat meningkat apabilah diperoleh adanya otonomi daerah. Sedangkan menurut bapak Sastra Waliza bahwa:

Pelayanan untuk publik adalah pelayanan yang wajib diselenggarakan negara untuk pemenuhan hak-hak dasar warga negara (publik). Ketiadaan atau kurang memadainya pelayanan publik berarti tidak terpenuhinya hak asasi manusia oleh pelayan publik tersebut (November 2019).

Menurut dari hasil wawancara dengan sekretaris PT. Tirta Remu Kota Sorong yang mengemukakan bahwa :

Salah satu faktor penting yang membuat PT. Tirta Remu ini dapat terlaksana sesuai dengan target yang di inginkan adalah untuk melihat tingkat kepuasan pelanggan terhadap pemakayan air yang di hasilkan oleh perusahan tersebut (November 2019).

Faktor Pendukung dan Penghambat Pelayanan Publik Pada PT. Tirta Remu

\section{Faktor Pendukung}

Pelayanan yang baik tidak terlepas dari faktor-faktor pendukung, baik itu fasilitas fisik maupun sumber daya manusia. Beberapa faktor pendukung tersebut yaitu:

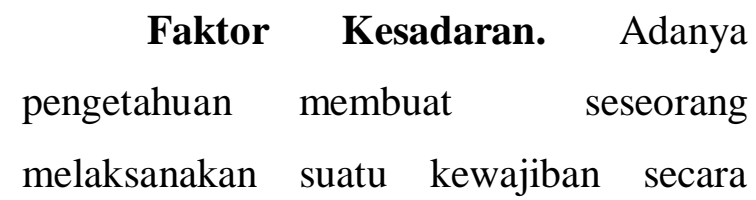

keikhlasan dan kesungguhan baik tertulis maupun tidak tertulis, mengikat semua orang dalam organisasi kerja. Oleh karena itu, dengan adanya kesadaran pada pegawai atau petugas diharapkan mereka mampu melaksanakan tugas dengan keikhlasan, kesungguhan dan kedisiplinan, dari hasil wawancara dengan seorang menejer teknik PT. Tirta Remu mengatakan bahwa:

Dengan adanya kerja sama yang baik sehinggadapat membawa seseorang kepada keikhlasan dan kesungguhan dalam menjalankan suatu tugas baik tertulis maupun tidak tertulis (November 2019).

Faktor Aturan. Dalam organisasi kerja aturan dibuat oleh manajemen sebagai pihak yang berwenang dan mengatur segala sesuatu yang ada di organisasi tersebut. Setiap aturan menyangkut terhadap manusia baik sebagai subyek aturan, artinya mereka yang membuat, menjalankan dan mengawasi pelaksanaan aturan maupun manusia sebagai obyek aturan, yaitu mereka yang dikenai oleh aturan itu, hal ini juga disampaikan oleh salah satu karyawan bahwa faktor aturan yaitu :

Aturan yang dapat dimiliki berdasarkan aturan-aturan perusahan PT. Tirta Remu kepada karyawan-karyawanya agar dapa mengerjakan suatu pekerjaan yang 
baik pada perusahan tersebut (November 2019).

Faktor Organisasi. Dalam organisasi pelayanan, organisasi tidak semata-mata dilihat sebagai perwujudan susunan organisasi, melainkan lebih banyak pengaturan dan mekanisme kerjanya yang harus mampu menghasilkan pelayanan yang memadai. Mekanisme organisasi memerlukan sarana pendukung untuk memperlancar mekanisme, yaitu sistem, prosedur, dan metode. Menurut bapak manager PT. Tirta Remu mengatakan bahwa:

Organisasi yang di bangun harus didukung dengan kinerja pegawai sehingga dalam bekerja mereka lebih terarah karena kinerja pegawai yang baik mencerminkan rasa tanggung jawab seseorang terhadap tugas yang diberikan kepadanya (November 2019).

Faktor Pendapatan. Pendapatan adalah seluruh penerimaan seseorang sebagai imbalan atas tenaga atau pikiran yang telah dicurahkan untuk orang lain atau badan/ organisasi dalam jangka waktu tertentu. Menurut hasil wawancara dengan salah satu karyawan bahwa :

Pendapatanyaitumenerima imbalan yang diberikan oleh perusahan PT. Tirta Remu kepada karyawanya atas tenaga atau pikiran yang telah dicurahkan untuk orang lain atau badan organisasi dalam jangka waktu tertentu (November2019).

Faktor Kemampuan dan Ketrampilan. Tugas/pekerjaan dapat dilakukan dengan baik apabilah memiliki kemampuan dan ketrampilan yang memadai,cepat dan memenuhi keinginan semua pihak, baik manajemen itu sendiri maupun masyarakat, hal tersebut sesuai dengan yang di kemukakan oleh manager umum bahwa tujuan dari faktor kemampuan dan ketrampilan yaitu:

Mampu menerangkan suatu tujuan yang ingin di capai kepada pihak lain dan membuat sesuatu hal yang ingin di capai tersebut menjadi menarik (November 2019).

Faktor Sarana Pelayanan. Sarana pelayanan yang dimaksud di sini adalah sejenis peralatan, perlengkapan kerja dan fasilitas lain yang berfungsi sebagai alat utama/pembantu dalam pelaksanaan pekerjaan sosial dalam rangka kepentingan orang-orang yang sedang berhubungan. Adapun fungsi sarana pelayanan tersebut antara lain: 1) Mempercepat proses pelaksannan pekerjaan, sehingga dapat menghemat waktu. 2) Barang dan jasa dapat Meningkatkan produktifitas, baik barang atau jasa. 3) Produk yang berkualitas akan menghasilkan suatu hasil produk yang baik. 4) Ketetapan susunan dan stabilitas ukuran terjamin. 5) Lebih 
mudah atau sederhana dalam para pelakunya. 6) Orang-orang yang berkepentingan akan merasa nyaman apabilah menciptakan kenyamanan

Sifat emosional dapat di kurangi dengan perasaan puas pada orang-orang yang berkepentingan, salah seorang manager administrasi yang di wawancarai mengatakan tentang faktor sarana pelayanan yaitu:

Bahwa faktor pelayanan yang di tetapkan oleh PT. Tirta Remu Kota Sorong relatif muda dan sederhana, mulai dari proses pelaksanaan sampai pada kualitasnya dan hampir semua karyawan membenarkan hal tersebut (November 2019).

\section{Faktor Penghambat}

Persepsi pelayanan pelanggan terhadap kualitas yang diberikan oleh perusahaan maupun instansi pelayanan umum, merupakan dasar usaha peningkatan kualitas pelayanan. Adapun faktor-faktor yang menghambat kualitas layanan yaitu: 1) Bawahan tidak dapat membuat keputusan apabilah belum ada ijin dari atasan. 2) Petugas sering bertindak kaku dan tidak memberi jalan keluar yang baik. 3) Petugas sulit di hubungi pada waktu jam kerja karena tidak ada di tempat. 4) Banyak interest pribadi dan aturan main yang tidak terbuka dan tidak jelas. 5) Kurang profesional (kurang terampil dalam menguasai bidangnya). 6) Banyak instansi atau bagian lain yang terlibat. 6) Disiplin kerja sangat kurang dan tidak tepat waktu.

Menurut salah satu karyawan mengatakan bahwa:

faktor pelayanan yang baik belum dicapai PT. Tirta Remu Kota Sorong, karena adanya faktor penghambat yang tidak mendukung pelayanan tersebut sehingga terjadi pelayanan yang tidak maksimal dan hampir semua karyawan merasa kesulitan (November 2019)

Disampingitu, ada juga salah satu karyawan yang mengemukakan bahwa :

Karyawan PT. Tirta Remu Kota Sorong tidak atau kurang mengikuti pelatihan atau pendidikan tambahan tentang pelayanan, sehingga pelanggan banyak mengelu kemampuan karyawan yang kurang memuaskan seperti, pencatatan meter yang kurang akurat, pelayananya lambat dan sebagainya, hal ini berpengaruh buruk terhadap kualitas pelayanan pada PT. Tirta Remu Kota Sorong (November 2019 ).

Menurut data yang diperoleh tentang tingkatan pendidiakan pegawai PT.Tirta Remu Kota Sorong dari segi pemerataan pelayanan dapat dilihat pada tabel berikut ini. 
Tabel: I Tingkat Pendidikan pegawai PT. Tirta Remu sebagai berikut

\begin{tabular}{cccl}
\hline NO & $\begin{array}{c}\text { Tingkat } \\
\text { Pendidikan }\end{array}$ & Jumlah & Presentase \\
\hline $\mathbf{1}$ & S1 & 25 & $20,00 \%$ \\
$\mathbf{2}$ & D3 & 3 & $2,40 \%$ \\
$\mathbf{3}$ & D2 & 2 & $1,40 \%$ \\
$\mathbf{4}$ & SMA & 87 & $69,60 \%$ \\
$\mathbf{5}$ & SMP & 5 & $4,00 \%$ \\
$\mathbf{6}$ & SD & 3 & $2,40 \%$ \\
& Jumlah & 125 & $100 \%$ \\
\hline
\end{tabular}

Sumber: PT Tirta Remu Kota Sorong tahun 2019

Dari table diatas menunjukan bahwa tingkat pendidikan pada Perusahan PT. Tirta Remu Kota Sorong yaitu S1 sebanyak 25 orang dengan Presentase 20,00\% D3 sebanyak 3 orang dengan Presentase 2,40\%, D2 sebanyak 2 orang dengan Presentase 1,40\%, SMA sebanyak 87 orang dengan Presentase 69,60 \%, SMP sebanyak 5 orang dengan Presentase $4,00 \%$, dan SD sebanyak 3 orang dengan presentasi $2,40 \%$.

\section{SIMPULAN}

Penelitian yang dilakukan pada PT. Tirta Remu Kota sorong menunjukkan bahwa adanya hubungan yang signifikan dalam pengaruh pengembangan sumber daya manusia terhadap pelayanan publik yaitu: PT. Tirta Remu Kota Sorong adalah salah satu perusahan yang mempunyai kopetensi dibidang urusan air minum kususnya di Kota Sorong; Pelayanan yang baik belum di capai oleh PT. Tirta Remu
Kota Sorong karena adanya faktor pendukung dan penghambat seperti, faktor kesadaran, faktor aturan, faktor organisasi, faktor pendapatan dan lain-lain; Pendidikan dan pelatihan masih sangat di perlukan oleh karyawan PT. Tirta Remu Kota Sorong untuk mencapai suatu organisasi yang Baik; Perlu adanya kerja sama antara pimpinan dan bawahan agar dapat meningkatkan kualitas pelayanan yang baik pada PT. Tirta Remu Kota Sorong.

\section{DAFTAR PUSTAKA}

Burhan Bungin (2007),Penelitian Kualitatif: komunikasi, ekonomi, kebijakan public danilmu social lainnya. Jakarta: Kencana.

Dessler, gary. 2011. Human Resource Management. McGraw-Hill. Series In Management. New York.

Melayu SP Hasibuan, 2007. Manajemen Sumber Daya Manusia Cetakan Kesembilan PT. Bumi Aksara, Jakarta.

Sugiyono (2011), Metode Penelitian Kuantitati Kualitatif Dan $R \& D$. Bandung: Penerbit Alfabeta.

Waluyo,2007 Manajemen Publik (Konsep Aplikasi dan Implementasi dalam pelaksanaan otonomi daerah), PT. Mandar Maju Bandung. 
Sudaryono. (2017). Pengantar Manajemen

Teori dan Kasus. CAPS:

Yogyakarta.

Sulistiyani, S., Amiruddin, A., \& Purnomo,

A. (2019). Pengembangan Sumber

Daya Manusia (SDM) Dalam

Kinerja Pegawai Distrik Aimas

Kabupaten Sorong. Jurnal Faksi:

Ilmu Sosial dan Ilmu Politik, 3(1), 32-40.

UU Nomor 22 Tahun 1999 Tentang Pemerintahan Daerah

UU Nomor 22 tahun 2001 tentang pemerintah Daerah

\section{PROFIL SINGKAT}

Penulis, Ana Lestari, lahir di Desa Bumejo, Kecamatan Kesamben, Kabupaten Blitar, Jawa Timut (JATIM), pada tanggal 03 September 1985. Pada jenjang pendidkan tinggi penulis mengikuti studi pada Jurusan Ilmu Administrasi Negara di Fakultas Ilmu Sosial dan Ilmu Politik, Universitas Muhammadiyah Sorong yang diselesaikan pada tahun 2010. Sebelum melanjutkan studi, Selanjutnya penulis melanjutkan studi S2 Pascasarjana Administrasi Negara, Universitas Muhammadiyah Jakarta, selesai pada tahun 2016. dan aktifitas sekarang yang dijalani sebagai Dosen tetap Universitas Muhammadiyah Sorong. 